\title{
Sociodemographic and Male's Involvement in Reproductive Health
}

\author{
Siti Novianti ${ }^{1}$, Rian Arie $\mathrm{G}^{2}$, Iseu Siti Aisyah ${ }^{3}$ \\ ${ }^{1,2,3}$ Faculty of Health Science, Siliwangi University Tasikmalaya West, Indonesia \\ sitinovianti@unsil.ac.id \\ rianarie@unsil.ac.id \\ iseusitiaisyah@unsil.ac.id
}

\begin{abstract}
Reproductive health is still considered part of the nature of women. The goal of the study was to evaluate the relationship between sociodemographics and male involvement. We conducted a population based cross sectional study in rural district of Nangtang Cigalontang Tasikmalaya. The study included 96 married man from couple of childbearing age. Bivarialte analysis was performed with chi square test. The study showes that the average age of the respondents $\mathbf{4 0 . 2}$ years, the majority of respondents' education level is primary school graduated $(\mathbf{7 7 . 1 \%})$. A total of $\mathbf{9 4 . 8 \%}$ of wife's education level is primary school graduated, $\mathbf{9 3 . 8 \%}$ as much as the wife does not work and the majority of respondents $(49 \%)$ have two children. Regarding male involvement, most husbands always took his wife to visit health services and accompany during childbirth. As many as $74 \%$ of couples agree to a contraceptive method, as much as $91 \%$ husband always talk to her about reproductive health issues. Results of bivariate analysis showed a significant association was found in a variable number of children $(p=$ $0.017)$ and the approval of the use of contraceptive methods ( $p=$ 0.007). While husband education variable, wife education and status of women working was not found a significant corelation. Men as well as women need to be involved in reproductive health issues. Involving men in reproductive health can lead a positive influence in strengthening relationship as a couple and improve better health to families.
\end{abstract}

Keywords - male, involvement, reproductive, health

\section{INTRODUCTION}

The reproductive health programmes have traditionally focused on women and the exclusion of men [1]. Men, especially in Africa, are dominant and are the major decision-makers in family affairs, including reproductive healthcare matters. The dominance of male in this respect is reinforced by the cultural institution of patriarchy, religion, and the economic power that men wield [2]. Male involvement in maternal health care has been described as a process of social and behavioural change that is needed for men to play more responsible roles in maternal health care with the purpose of ensuring women's and children's wellbeing [3].
Reasons for involving men in reproductive health matters are multifaceted. First of all, men have their own reproductive health concerns and their involvement should not be seen only as a means to achieve women's better reproductive healthcare. Second, men's sexual and reproductive well-being and behaviours directly affect their partners. Third, decisions on the matters of reproductive healthcare occur within relationships that affect both men and women [4]. As in the case of some other countries, men in Indonesia generally have a dominant role and being decision makers in the affairs of the family, including in terms of reproductive health. Male dominance in this case reinforced by patriarchal culture, religion and economic power that men have. Increasing the perceptions of men through involvement in various reproductive activities is believed to produce synergistic effects that could be a greater integration of reproductive health matters with the MDGs [5].

The involvement of men in reproductive health in Indonesia was still low compared to other developing countries such as Pakistan (5.2\%), Bangladesh (13.9\%), Malaysia (16.8\%). Male participation especially the achievement of condoms and vasectomy $1.3 \% \quad 0.2 \%$, while the goals of the National Medium Term Development Plan increased to $4.5 \%$ [6]. One reason for the low participation of men in family planning was the lack of information about the benefits of family planning for men as a whole and there is still the assumption that family planning is a matter for women only [7]. In addition to the use of contraceptives, the involvement of men in reproductive health services were communication between husband and wife. The communication 
included men involvement in bringing his wife visiting health services, including accompany childbirth. Male participation in family planning in Tasikmalaya district was also still very low. Of the total 391.221 couples of childbeariang age by 2013 , which became acceptors amounted to $64.91 \%$, where male contraceptive methods (vasectomy and condoms) is only $1.22 \%$. Cigalontang District was one area that has low coverage comparing to other areas in the district of Tasikmalaya [8]. Other than as acceptors of family planning, this study is also to find out how the role of male involvement in reproductive health.

\section{METHODS}

\section{A. Study Population}

We used data form a population-based cross sectional study involving married males in rural district of Nangtang Cigalontang Tasikmalaya West Java as sampling frame. In total, 96 men were ramdomly selected for the study.

\section{B. Data Collection}

In person interviewed were conducted to collect information on sociodemographic characteristics, cultural factors and the use of family planning method. The male's involvement include spousal communication of men, accompanying wives during visits to clininc and their delivery care, currently used contraceptive method, male always discuss with wife about the reproductive health issues. Male's involvement were divided into two categories. High category if it is involved in at least two involvement activities about health reproductive matters.

\section{Statistical Analysis}

Data were analyzed using the SPSS sofware for Windows (version 17). Bivariate analysis was performed between male's involvement as the dependent variable and each sociodemographic factors as the independent variable by chi square test.

\section{RESULT}

The distribution of sociodemographic variables, as seen in Table 1.
TABLE I

SOCIODEMOGRAPHIC CHARACTERISTICS OF RESPONDENTS (N=96)

\begin{tabular}{|c|c|c|}
\hline Sociodemographic variables & Frequency & Percentage \\
\hline $\begin{array}{l}\text { Age } \\
\text { Average: } 42,20 \text { tahun }( \pm 9,3)\end{array}$ & & \\
\hline $\begin{array}{l}\text { Level of Education } \\
\text { Not Finished Primary School } \\
\text { Primary School Graduated } \\
\text { Elementary School Graduated } \\
\text { High School Graduated }\end{array}$ & $\begin{array}{r}3 \\
74 \\
11 \\
8\end{array}$ & $\begin{array}{r}3,1 \\
77,1 \\
11,5 \\
8,3\end{array}$ \\
\hline $\begin{array}{l}\text { Occupation } \\
\text { Labour } \\
\text { Farmer } \\
\text { government employees } \\
\text { Private sector worker } \\
\text { Trade/Entreperneur }\end{array}$ & $\begin{array}{r}34 \\
14 \\
1 \\
2 \\
45\end{array}$ & $\begin{array}{r}35,4 \\
14,6 \\
1,0 \\
2,1 \\
46,9\end{array}$ \\
\hline $\begin{array}{l}\text { Education Level of Wife } \\
\text { Primary School Graduated } \\
\text { Elementary School Graduated } \\
\text { High School Graduated } \\
\text { Diploma Graduated }\end{array}$ & $\begin{array}{r}24 \\
2 \\
2 \\
1\end{array}$ & $\begin{array}{r}94,8 \\
2,1 \\
2,1 \\
1,0\end{array}$ \\
\hline $\begin{array}{l}\text { Working Wife } \\
\text { Yes } \\
\text { No }\end{array}$ & $\begin{array}{r}6 \\
90\end{array}$ & $\begin{array}{r}6,2 \\
93,8\end{array}$ \\
\hline $\begin{array}{l}\text { Number of Life Children } \\
1 \text { child } \\
2 \text { children } \\
3 \text { children } \\
4 \text { children } \\
5 \text { children } \\
8 \text { children } \\
\text { Average : } 2,2( \pm 1,05)\end{array}$ & $\begin{array}{r}20 \\
47 \\
23 \\
3 \\
2 \\
1\end{array}$ & $\begin{array}{r}20,8 \\
49,0 \\
24,0 \\
3,1 \\
2,1 \\
1,0\end{array}$ \\
\hline
\end{tabular}

The average age of respondents was 40.2 years, the majority of respondents education level is primary school graduated $(77.1 \%)$ and trade / entrepreneurs $(46.9 \%)$ is largely of respondents occupation. As many as $94.8 \%$ of wife's education level is primary school, graduated $93.8 \%$ as much as the majority respondents of no working wife $(49 \%)$ have two children with the average number of children was 2.2.

TABLE II

MALE'S INVOLVEMENT (N=96)

\begin{tabular}{|l|r|r|}
\hline Variable & Frequency & Percentage \\
\hline $\begin{array}{l}\text { Husband always took his wife to visit } \\
\text { health care (including accompanied } \\
\text { during childbirth) }\end{array}$ & \\
$\quad$ Yes & 59 & \\
No & 37 & \\
\hline Currently (husband /wife) used a & & \\
contraceptive method & & \\
\hline
\end{tabular}




\begin{tabular}{|c|r|r|}
\hline Yes & 93 & 96,9 \\
No & 3 & 3,1 \\
\hline Couple approved contraceptive & & \\
method & 74 & 77,1 \\
Yes & 22 & 22,9 \\
No & & \\
\hline Husband always discuss with wife & \\
about the reproductive health issues & 88 & 91,7 \\
Yes & 8 & 8,3 \\
No & \\
\hline
\end{tabular}

Distribution of male's involvement in reproductive health seen in Table 2 . The majority of husband who always took his wife to visit health services and accompany during childbirth. A total of $77.1 \%$ of couples agree to a contraceptive method, as much as $91 \%$ husband always talk to his wife about reproductive health issues.

TABLE III

BIVARIATE ANALYSIS BETWEEN SOCIODEMOGRAPHIC AND MALE'S INVOLVEMENT IN REPRODUCTIVE HEALTH (N=96)

\begin{tabular}{|c|c|c|c|}
\hline \multirow[t]{2}{*}{ Variable } & \multicolumn{2}{|c|}{$\begin{array}{c}\text { Male Involvement in } \\
\text { Reproductive Health Services }\end{array}$} & \multirow[t]{2}{*}{$\begin{array}{c}P \\
\text { value }\end{array}$} \\
\hline & $\operatorname{Low}(n=39)$ & High $(\mathrm{n}=57)$ & \\
\hline $\begin{array}{l}\text { Number of Children } \\
-\quad \text { Have No Children } \\
-\quad 1-2 \text { children } \\
-\quad 3+\text { children }\end{array}$ & $\begin{array}{c}13(33,3) \\
19(48,7) \\
7(18,0)\end{array}$ & $\begin{array}{c}7(12,3) \\
28(49,1) \\
22(38,6)\end{array}$ & 0,017 \\
\hline $\begin{array}{l}\text { Husband Education } \\
-\quad \text { Low } \\
-\quad \text { High }\end{array}$ & $\begin{array}{c}37(94,9) \\
2(5,1)\end{array}$ & $\begin{array}{l}51(89,5) \\
6(10,5)\end{array}$ & 0,957 \\
\hline $\begin{array}{l}\text { Working Wife } \\
-\quad \text { No } \\
-\quad \text { Yes }\end{array}$ & $\begin{array}{c}36(92,3) \\
3(7,7)\end{array}$ & $\begin{array}{c}54(94,7) \\
3(5,3)\end{array}$ & 0,957 \\
\hline 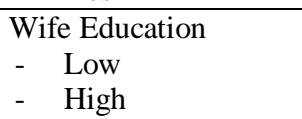 & $\begin{aligned} 38 & (97,4) \\
1 & (2,6)\end{aligned}$ & $\begin{array}{l}53(93,0) \\
4(7,0)\end{array}$ & 0,646 \\
\hline
\end{tabular}

Table 3. shows the results of the bivariate analysis of the relationship between sociodemographic variables with the male's involvement in reproductive health. Significant relationship was found in a variable number of children $(p=0.017)$ and the approval of the use of contraceptive methods $(p=0.007)$. While husband education variable, educational wife and status of women working was not found a significant relationship. The man with number of three or more children have a good participation compared with men who do not have children or have 1-2 children.
The results of this study didnt found statistically significant from the level of education variable. The proportion of male's involvement in categorized high ( 58\%) was found in respondents with low education levels. Men who approve their partners to use contraceptives was more common in male respondents who have a good participation in reproductive health than men who did not agree his partner to use a contraceptive method.

\section{CONCLUSIONS}

The husband's role during the perinatal period was explained by gender-specific reasons - house hold chores were women's job, men only assist when the woman is pregnant and cannot manage to perform [9]. Traditionally, pregnancy and childbirth are seen as women events and husbands do not take part. Older women in the community, like mothers, grandmothers and mothers-in-law were trusted and perceived knowledgeable about childbirth issues [10]. It is slightly different to that found in the Indonesian culture, both in urban and in rural as found in this studi in Nangtang Karangnunggal Tasikmalaya. This culture is also influenced by the religion of islam which is the majority, where the husband is recommended to accompany his wife during the childbirth, while once the baby is born, the husband or the father of the baby is usually directly azan and iqomat in the ears of his newborn.

Though formally have a low education level, generally in rural communities included in the district of Nangtang Cigalontang have been exposed information about family planning, through family planning officer and health cadres. Male involevement in whole aspect of reproductive health including reproductive health knowledge, intra-spousal communication, and method of family planning can lead a positive influence in strengthening relationship as a couple and improve better health to families.

\section{ACKNOWLEDGEMENT}

The Authors thank Siliwangi University for funding the study. Our thanks also extended to data collectors and man in Cigalontang villages for their cooperation in the study. 


\section{REFERENCES}

[1] Reproductive Health Outlook, PATH (RHO) 2003 Men and reproductive health. www.igwg.org/igwg_media/rhowebsite2004.pdf.

[2] Ezeh AC 1993 The influence of spouses on each other's contraceptive attitudes in Ghana. Stud Fam Plann 24(3):163-174.

[3] United Nations. Report of the International Conference on Population and Development. A/CONF. 171/13/Rev.1, 11-34. 1995. Cairo, Egypt Retrieved

http://www.ippf.org/en/About/ICPD+Programme+of+Action.htm on 10-10-2009.

[4] Kaushalendra KS, Shelah SB, Amy OT 1998 Husbands' reproductive health, knowledge, attitudes and behavior in Uttar Pradesh, India Stud Fam Plann 29(4):388-399.

[5] Shahjahan et al. 2013 Determinants of male participation in reproductive healthcare services: a cross-sectional study Reproductive Health 10:27.
[6] BKKBN 2007 Factors Affecting The Low Participation of Men in Family Planning http://www.bkkbn.go.id/gemapria/infodetail.php?infid $=79$

[7] Purwanti, H 2011 Effort to Increase Male Participation in Reproductive Health and Family Planning as a Form of Gender Equality. Journal of Argumentum Vol. 10(2) June

[8] Karangnunggal Primary Health Service 2013 Yearly Report of Karangnunggal Primary Health Service

[9] Kululungga, et all 2012 Male Involvement in Maternity Health Care in Malawi Afr J Reprod Health 16[1]:145-157)

[10] Seljeskog L, Sundby J and Chimango J 2006 Factors influencing women's choice of place of delivery in rural Malawi--an explorative study. Afr J Reprod Health 10(3):66-75 